\title{
NGO지원사업 종합평가
}

경희대학교 NGO대학원 평가팀

목차
I. 평가개요
II. ODA 질적 평가 보고서 내용
III. 한국국제협력단 NGO지원사업 분석
IV. NGO지원사업 현지평가 : 몽골· 탄자니아
V. 정책함의 및 제언

\section{I. 평가개요}

\section{1. 평가목적과 배경}

○ 'NGO지원사업'은 선진공여국이 전통적으로 수행해온 원조양식이며, 국제개발협력에 있어 정부 의 $\mathrm{ODA}$ 와는 다른 차별성 있는 역할을 하고 있음. 국제사회는 정부차원의 사업실시가 어려운 지 역과 $\mathrm{NGO}$ 가 보다 효율적으로 집행할 수 있는 사업을 위해 $\mathrm{NGO}$ 의 사업참여를 확대하고 있음.

O KOICA는 1995년부터 'NGO지원사업'을 실행하고 있으며, 개발협력에 대한 국제사회의 흐름과 한국정부의 ODA 증대에 따라 더욱 효과적인 NGO 사업의 개선이 요청되고 있음. 2010년 10월 국제개발협력위원회에서 의결한 〈ODA 선진화 방안〉에 따르면 KOICA도 2015년까지 NGO를 통한 ODA자금 지원이 현재의 약 10 배인 900 억원 수준으로 확대될 예정임. 
○ 이에, 본 평가는 첫째, $\mathrm{KOICA}$ 의 'NGO지원사업 전략'을 평가하여 '한국형 $\mathrm{NGO}$ 지원사업전략' 수립에 기여하며 둘째, 효율적, 효과적인 'NGO지원사업 수행절차 개선안'을 제시하고 셋째, 몽 골·탄자니아 현지 평가를 통한 'NGO지원사업의 현지실행 개선안' 제시를 목적으로 광범위한 문헌조사, 몽골, 탄자니아 현장방문 평가, 인터뷰와 설문실시 및 토론회 개최 등 다양한 평가 방법을 통해 종합적인 평가를 실시함.

\section{2. 평가팀 구성}

〈표 1〉경희대학교 NGO대학원 NGO지원사업평가 연구팀 구성

\begin{tabular}{|c|l|l|}
\hline 역할 & \multicolumn{1}{|c|}{ 이름 } & \multicolumn{1}{c|}{ 소속 } \\
\hline 연구책임자 & 손혁상 & 경희대학교 NGO대학원 교수 \\
\hline \multirow{4}{*}{ 공동연구원 } & 정복철 & 경희대학교 교양학부 교수 \\
\cline { 2 - 3 } & 안성식 & 경희사이버대학교 교수 \\
\cline { 2 - 3 } & 한재광 & ODA Watch 사무국장 \\
\cline { 2 - 3 } & 박보기 & 경희대학교 인류사회재건연구원 연구원 \\
\hline \multirow{3}{*}{ 연구보조원 } & 서진희 & 경희대학교 NGO대학원 석사과정 \\
\cline { 2 - 3 } & 이윤미 & 경희대학교 국제대학원 석사과정 \\
\cline { 2 - 3 } & 최승진 & 경희대학교 NGO대학원 석사과정 \\
\hline \multirow{2}{*}{ 자문위원 } & 권 율 & 대외경제정책연구원 \\
\hline \multirow{2}{*}{ 해외 컨설턴트 } & 이해균 & 한국교육기술대학교 \\
\cline { 2 - 3 } & 허남운 & 탄자니아 \\
\cline { 2 - 3 } & Togsbayar Dashtseren & 몽골 \\
\hline
\end{tabular}

\section{3. 평가방법}

응가범위를 $\mathrm{NGO}$ 지원사업 전략, 수행절차, 현지사업수행으로 설정하고 이에 따른 평가기준 및 방법을 선정함.

○ 문헌조사를 통해 주요 선진공여국 $\mathrm{NGO}$ 지원사업 조사·분석과 이에 기초하여 KOICA NGO지원 사업의 개선 방향점을 도출하며, 국내조사로 국내NGO 설문조사를 통해 KOICA NGO지원사업 의 정책과 사업수행절차에 관한 의견수렴 및 인식을 분석함. 현지조사로는 KOICA 현지사무소 관계자, 사업수행 NGO 책임자 및 관계자 인터뷰 및 설문조사로 NGO지원사업이 수행되는 현 장에서의 개선점을 파악함. 
○ 그 외, 전문가 인터뷰 및 타깃그룹별 인터뷰(FGI), 공개심포지움 등을 통해 평가의 질적 제고 및 정책대안 제시를 위한 의견수렴과 인식을 공유함.

\section{4. 평가매트릭스}

○ NGO지원사업 전략

〈표 2〉NGO지원사업 전략 평가매트릭스

\begin{tabular}{|c|c|c|c|c|}
\hline 평가대상 & 평가기준 & 평가항목 & 평가방식 & 자료 및 정보소스 \\
\hline \multirow{7}{*}{$\mathrm{KOICA}$} & \multirow{5}{*}{ 적절성 } & 사업목적 & \multirow{7}{*}{$\begin{array}{l}\text { 문헌조사 } \\
\text { 인터뷰 } \\
\text { (KOICA } \\
\text { 본부 } \\
\text { 관계자) }\end{array}$} & \multirow{7}{*}{$\begin{array}{l}\text { - OECD/DAC 주요 선진공여국의 NGO지원사업과의 비교분석 } \\
\text { - ODA의 NGO지원사업에 대한 각종 연구서 } \\
\text { - 한국ODA 발전관련 각종 정책 } \\
\text { - OECD/DAC 통계분석 } \\
\text { - KOICA 중기전략문서검토 } \\
\text { - } 2007 \text { 2009년 KOICA NGO지원사업 관련 문서 } \\
\text { - KOICA의 NGO지원전략 및 관련 자료 } \\
\text { - 사업지역 국가의 개발계획 조사 } \\
\text { - 총리실, 외교부관계자 인터뷰 }\end{array}$} \\
\hline & & 사업전략 & & \\
\hline & & 사업규모 & & \\
\hline & & 사업지역 & & \\
\hline & & 사업기준 & & \\
\hline & \multirow{2}{*}{ 효율성 } & 사업방식 & & \\
\hline & & 사업체계 & & \\
\hline \multirow{6}{*}{ NGO } & \multirow{5}{*}{ 적절성 } & 사업목적 & \multirow{6}{*}{$\begin{array}{c}\text { 문헌조사 } \\
\text { 인터뷰 } \\
\text { (NGO } \\
\text { 본부 } \\
\text { 관계자) }\end{array}$} & \multirow{6}{*}{$\begin{array}{l}\text { - 2007 2009년 NGO사업 관련 문서 및 자료 } \\
\text { - 몽골 및 탄자니아 ODA 관련 문서 및 자료 } \\
\text { - 몽골 및 탄자니아 NGO지원사업 관련 사업 문서 및 자료 } \\
\text { - 몽골, 탄자니아 국가개발계획 및 관련 자료 }\end{array}$} \\
\hline & & 사업전략 & & \\
\hline & & 사업지역 & & \\
\hline & & 사업기준 & & \\
\hline & & 정책수용성 & & \\
\hline & 효율성 & 사업방식 & & \\
\hline
\end{tabular}

○ NGO지원사업 수행절차

〈표 3〉NGO지원사업 수행절차 평가매트릭스

\begin{tabular}{|c|c|c|c|c|}
\hline 평가대상 & 평가기준 & 평가항목 & 평가방식 & 자료 및 정보소스 \\
\hline \multirow{11}{*}{ KOICA } & \multirow{4}{*}{ 적절성 } & 사업선정기준 & \multirow{11}{*}{$\begin{array}{c}\text { 문헌조사 } \\
\text { 인터뷰 } \\
\text { (KOICA 본부 관계자) }\end{array}$} & \multirow{4}{*}{$\begin{array}{l}\text { - OECD/DAC 주요 선진공여국 NGO지원사업 } \\
\text { 제도 및 관련 자료 } \\
\text { - KOICA NGO지원사업 관련 문서 및 자료 }\end{array}$} \\
\hline & & 예산 & & \\
\hline & & 사업계획 & & \\
\hline & & 사업평가 & & \\
\hline & \multirow{4}{*}{ 효율성 } & 사업심사 & & \multirow{7}{*}{$\begin{array}{l}\text { - KOICA NGO지원사업 심사 관련 문서 및 자료 } \\
\text { - KOICA 사업평가 관련 문서 및 자료 } \\
\text { - KOICA 사업계획서 및 보고서 }\end{array}$} \\
\hline & & 사업평가 & & \\
\hline & & 의사소통 & & \\
\hline & & 수월성 & & \\
\hline & \multirow{2}{*}{ 효과성 } & 사업평가 & & \\
\hline & & 의사소통 & & \\
\hline & 영향력 & 평가반영 & & \\
\hline
\end{tabular}




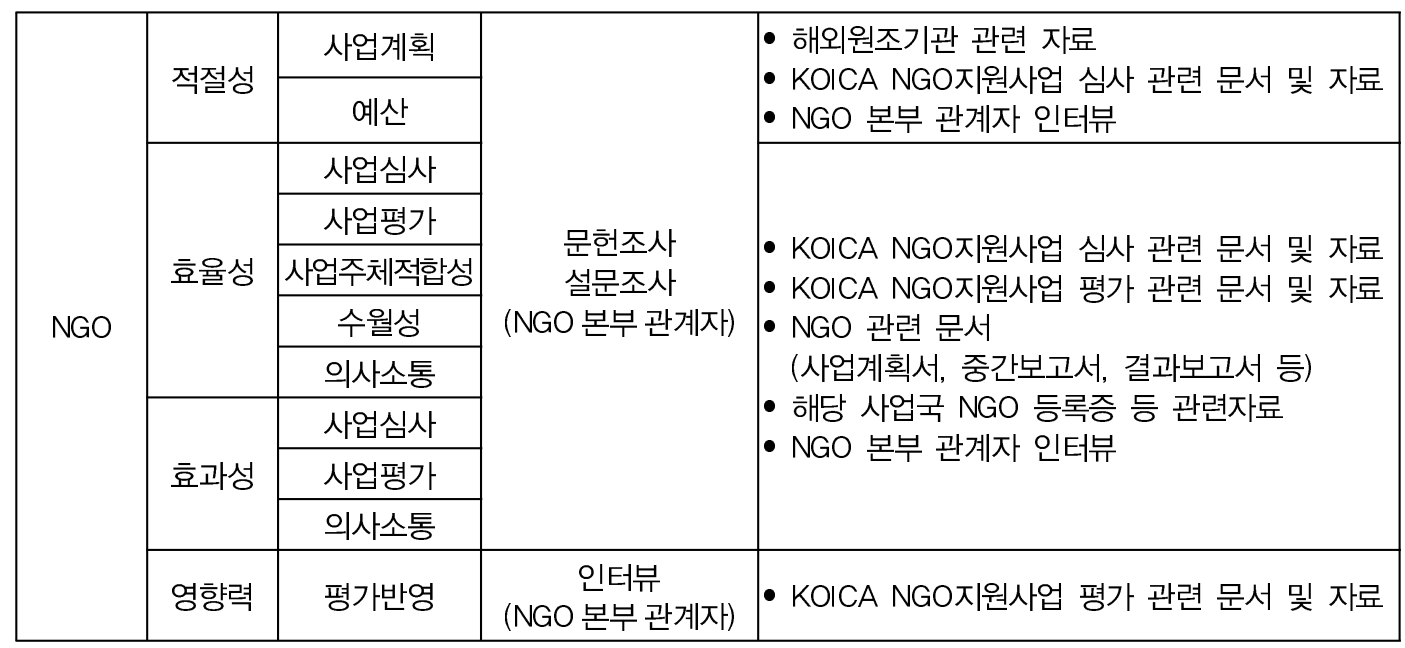

현지평가

〈표4〉 현지평가 평가매트릭스

\begin{tabular}{|c|c|c|c|c|}
\hline 평가대상 & 평가기준 & 평가방식 & 평가범위 & 자료 및 정보소스 \\
\hline \multirow[t]{4}{*}{$\mathrm{KOICA}$} & 적절성 & \multirow{4}{*}{$\begin{array}{l}\text { 문헌조사 } \\
\text { 인터뷰 } \\
\text { (KOICA } \\
\text { 현지사무소 } \\
\text { 관계자) }\end{array}$} & $\begin{array}{l}\text { - 해당 국가의 발전전략 및 정책과의 } \\
\text { - 부합성 } \\
\text { - 원조효과성 제고를 위한 한국 내 } \\
\text { 원조조화성 } \\
\text { - NGO지원사업의 현지수요 반영 정도 } \\
\text { - 전략적 사업진행 정도 } \\
\text { - 정책수용 정도 } \\
\text { - 해당 국가의 NGO지원사업의 수용성 }\end{array}$ & $\begin{array}{l}\text { - 몽골 및 탄자니아 국가개계획 } \\
\text { 및 전략 관련 자료 } \\
\text { - 몽골 및 탄자니아 } \\
\text { 국별지원전략(CAS) } \\
\text { - KOICA 현지사무소 관련문서 } \\
\text { 및 자료 } \\
\text { - 사업지역 내 선진 공여국 } \\
\text { 관계자 인터뷰 } \\
\text { - 해당국가 정부 관계자 인터뷰 }\end{array}$ \\
\hline & 효율성 & & $\begin{array}{l}\text { 현지사무소와의 협력관계, 의사소통 } \\
\text { 빈도, 질 등 }\end{array}$ & \multirow{3}{*}{$\begin{array}{l}\text { - KOICA 현지사무소 관련문서 } \\
\text { 및 자료 } \\
\text { - KOICA 본부관계자 인터뷰 } \\
\text { - 해당국가 정부 관계자 인터뷰 }\end{array}$} \\
\hline & 효과성 & & $\begin{array}{l}\text { KOICA 현지사무소의 사업타당성 } \\
\text { 조사방식 및 내용 }\end{array}$ & \\
\hline & $\begin{array}{l}\text { 지속 } \\
\text { 가능성 }\end{array}$ & & 사업수행 $\mathrm{NGO}$ 의 지속가능성 역량 정도 & \\
\hline \multirow{5}{*}{ NGO } & 적절성 & \multirow{5}{*}{$\begin{array}{l}\text { 문헌조사 } \\
\text { 인터뷰 } \\
\text { (NGO } \\
\text { 현지사무소 } \\
\text { 관계자) }\end{array}$} & $\begin{array}{l}\text { 사업수행국가 정부와의 관계성, 정기적 } \\
\text { 협의, 모니터링, 평가과정 }\end{array}$ & \multirow{5}{*}{$\begin{array}{l}\text { - NGO 사업문서 및 자료 } \\
\text { - NGO 본부관계자 인터뷰 }\end{array}$} \\
\hline & 효율성 & & $\begin{array}{l}\text { - KOICA 현지사무소와의 협력관계, } \\
\text { 의사소통 빈도와 질 } \\
\text { - 내외부 사업 평가시스템 및 모니터링 }\end{array}$ & \\
\hline & 효과성 & & 사업전담체계 및 전문성 & \\
\hline & 영향력 & & $\begin{array}{l}\text { 사업대상 그룹의 실제 사업수혜 및 } \\
\text { 역량강화 }\end{array}$ & \\
\hline & $\begin{array}{l}\text { 지속 } \\
\text { 가능성 }\end{array}$ & & $\begin{array}{l}\text { - KOICA 지원의 기여 정도 } \\
\text { - 사후관리체계 준비 정도 } \\
\text { - 현지사회로의 사업위임정도 및 가능성 }\end{array}$ & \\
\hline
\end{tabular}




\begin{tabular}{|c|c|c|c|c|}
\hline \multirow{5}{*}{$\begin{array}{l}\text { 지역 } \\
\text { 사회 }\end{array}$} & 적절성 & \multirow{5}{*}{$\begin{array}{c}\text { 문헌조사 } \\
\text { 인터뷰 } \\
\text { (사업지역 } \\
\text { 행정관계자, } \\
\text { 지역지도자 } \\
\text { 및 주민) }\end{array}$} & $\begin{array}{l}\mathrm{NGO} \text { 의 사업에 대한 현지사회의 적절성 } \\
\text { 판단 }\end{array}$ & \multirow{5}{*}{$\begin{array}{l}\text { • 현지 지방정부 발전계획 및 } \\
\text { 관련 자료 }\end{array}$} \\
\hline & 효율성 & & $\begin{array}{l}\text { 사업수행 국가 정부와의 관계성 및 참여 } \\
\text { 정도 }\end{array}$ & \\
\hline & 효과성 & & 지역사회 발전 및 자체역량 강화 기여 정도 & \\
\hline & 영향력 & & $\begin{array}{l}\text { - 양성평등 및 환경에 대한 영향력 } \\
\text { - 사업수혜자 그룹의 역량강화 }\end{array}$ & \\
\hline & $\begin{array}{l}\text { 지속 } \\
\text { 가능성 }\end{array}$ & & $\begin{array}{l}\text { 현지 지역사회의 자력화 } \\
\text { (empowerment) }\end{array}$ & \\
\hline
\end{tabular}

\section{II. 선진공여국 NGO지원사업 현황}

\section{1. 국제사회 NGO지원사업}

O 국제 선진공여사회는 국제개발에 있어 개발NGO가 다자간, 양자간 원 조기구와는 차별성 및 전 략적 강점을 보유하고 있다고 인정하며, $\mathrm{ODA}$ 지원을 통해 개발 $\mathrm{NGO}$ 의 특성 및 강점을 활용하 여 국제개발에 기여하는 방식을 활용해오고 있음.

O 국제NGO 직접지원을 포함할 경우〈표5〉에 나타나듯이 DAC회원국의 전체 순지출 양자간 ODA 대비 NGO지원 평균비율이 2005년 4.14\%에서 2007년 9.36\%, 2008년 11.14\%로 급격히 높아 지고 있는 추세임.

〈표 5〉2005 2008 OECD/DAC 회원국의 ODA대비 NGO지원금 규모

(단위 : 백만달러)

\begin{tabular}{|c|c|c|c|c|}
\hline 년도 & 2005 & 2006 & 2007 & 2008 \\
\hline 순지출 기준 양자간ODA 규모 & 96,606 & $100,509.9$ & $90,769.5$ & $114,147.6$ \\
\hline 순지출 기준 양자간 ODA중 NGO지원 규모 & $4,001.9$ & $9,452.1$ & $8,494.2$ & $12,715.2$ \\
\hline 순지출 기준 양자간 ODA중 NGO지원 비율 & $4.14 \%$ & $9.4 \%$ & $9.36 \%$ & $11.14 \%$ \\
\hline
\end{tabular}

※ 출처 : $\mathrm{OECD}$ 의 공식 통계시스템인 CRS(Creditor Recording Sysytem. (http://stats.oecd.org/Index.aspx? DatasetCode=CRSNEW)에서 2005년부터 2008년까지 NGO\&Civil Society를 Channel로 지원하는 내용을 조 건으로 설정하여 결과로 나온 내용이다. 그러나 이 내용에는 DAC회원 국가들이 자국NGO외에 국제NGO(예: International trust fund for demining and mine victims assistance, International Committee of the Red Cross)에 지원하는 경우도 포함하여 일반적으로 이야기 되는 자국NGO지원 비율보다 다소 높다. 
O 현재 $\mathrm{NGO}$ 를 통한 $\mathrm{ODA}$ 집행에 관한 국제사회의 주요 이슈는 크게 '원조효과성' 접근과 '개도국 시민사회지원' 및 ' $\mathrm{NGO}$ 들의 자체 효과성 논의'로 볼 수 있음.1) 전자는 2000 년대 이후 국제공 여자 사회의 주요 이슈인 '원조효과성' 논의가 정부간 사업뿐만 아니라 개발 $\mathrm{NGO}$ 에게도 적용되 어야 한다는 접근임. 후자는 근본적으로 개발 $\mathrm{NGO}$ 의 역할이 정부ODA의 효과적 집행 '수단'인 지 혹은 ‘목적'으로서의 개도국 시민사회지원을 지향하는지에 대한 방향성과 관련된 접근임. 이 와 관련하여 학계에서는 개발NGO들이 개발사업을 집행하는 효율적인 관리 수단에만 관심을 두고 있는 것을 비판하며, 근본적인 개발의 방향에 대한 문제제기와 대안발전방안 제시에 힘쓸 것을 제안함. ${ }^{2)}$

\section{2. 주요 선진공여국 비교·분석}

이국, 스웨덴, 스위스, 영국, 일본, 캐나다 및 호주 등 7 개 선진원조 공여국의 NGO지원사업을 비교·분석하여 한국의 제도에 대한 시사점을 찾으면 다음과 같음.

O 7 개국의 $\mathrm{NGO}$ 지원사업의 목적은 '개도국 빈곤감소', '개도국 시민사회 발전'을 두 축으로 하고 이에 각국의 상황에 맞는 내용을 추가하고 있음.

○ 7 개국의 $\mathrm{NGO}$ 지원사업 담당기관은 중앙정부 담당부처와 정부원조전담기관으로 이원화된 형태 와 정부원조전담기관이 총괄해서 진행하는 경우로 나누어짐.

O 7 개국은 수원국 현지요구의 다양성과 $\mathrm{NGO}$ 의 특성화에 따라 다양한 목적을 가진 $\mathrm{NGO}$ 지원사업 을 폭넓게 운영하고 있음.

○ 7 개국은 거의 모든 국가가 사업비를 전액 지원하는 일괄지원방식(Block Grant)과 정부와 NGO 가 공동으로 부담하는 공동자금협력방식(Matching Grant)을 혼용하여 활용함.

O 2009년 OECD의 자료 ${ }^{3)}$ 를 보면 ODA 대비 NGO지원 비율과 규모는 본 연구의 조사 대상인 7

1) Giffen Janice., and Ruth Judge. 2010. "Civil Society Policy and Practice in Donor Agencies" INTRAC

2) Bebbington, Anthony., J. Samuel Hickey and Diana C. Mitlin. 2008. "Can NGOs Make a Difference?, The Challenge of Development Alternative." In Can NGOs Make a Difference?, ed. Bebbington, Anthony., J. Samuel Hickey and Diana C. Mitlin. New York: Zed Books LTD, 5-34.

3) ODA 연구중 NGO를 지원하는 비율은 통일된 자료를 확보하기 매우 어렵다. 이는 각국이 OECD에 보고하는 통계와 연 간보고서에 제출하는 통계 등에서 자국 NGO지원 외에 개도국NGO지원, 긴급구호자금, 개발인지자금 등을 엄밀히 구분 하여 사용하지 않기 때문이다. 그래서 각국의 NGO지원 총계를 단순히 비교하기엔 어려움이 있다. 
개국 중 스웨덴이 4\%(190.1백만달러), 미국이 4\%(1148백만달러)로 가장 큼. 그 뒤로 스위스가 $3 \%$ (69.35백만달러), 영국이 2.5\%(323.57백만달러)임. 일본 1.2\%(122.76백만달러), 호주 $1 \%$ (29.11 백만달러), 캐나다는 $1 \%(40.91$ 백만달러)임. 한국은 $0.9 \%$ (7.37백만달러)오 규모와 비율이 타국 에 비해 낮은 수준임.

O 7 개국의 $\mathrm{NGO}$ 지원사업 기간은 제한이 있는 경우와 없는 경우로 구분되며, 대체로 단년도보다 는 다년도로 지원함.

O 7 개국의 $\mathrm{NGO}$ 지원사업의 지원대상은 대상을 넓히기 위해 특별한 제한을 두지 않는 보편성의 특징과 일정기준 이상의 단체만 참여를 허용하는 자격제한성의 특징을 보임.

O 7 개국은 NGO지원사업을 위해 공통적으로 사업계획서, 단체소개서 및 재정계획서를 요청함. 공 통서류 외에 국가별로 특별히 요청하는 서류들이 있음.

O 7 개국은 $\mathrm{NGO}$ 지원사업을 통해 다양한 분야의 개발협력 사업을 지원함. 그 분야는 국제개발협 력의 전통적인 지원분야인 인간기본욕구(Basic Human Needs:BHN) 및 긴급구호 외에도, 각 국가가 지향하는 대외외교정책 및 원조정책과 관련성이 깊음.

○ 7 개국은 $\mathrm{NGO}$ 지원사업 관련 전략문서 및 재정, 관리, 지원, 평가에 관한 독립된 정책문서들을 보유하고 있음.

O 7 개국의 $\mathrm{NGO}$ 협력방식에는 정부원조기관과 개별NGO가 일대일로 사업을 협력하는 방식과 스웨 덴의 Framework Organization과 같이 $\mathrm{NGO}$ 협의체를 통해 사업에 참여하는 $\mathrm{NGO}$ 를 선정, 지 원, 평가하는 방식이 있음.

O 7 개국은 $\mathrm{NGO}$ 지원사업에 대해 공통적으로 사업중간 및 결과보고서와 재정보고서 제출 후 검토 를 통한 평가를 실시함. 이후 필요시 현장을 방문하여 평가함.

○ 7 개국 중 일본과 스웨덴은 다양한 NGO 역량강화 프로젝트를 가지고 있음.

ㅇ 7 개국 중 다수는 개도국 현지 $\mathrm{NGO}$ 에 대해 직접간접적으로 재정을 지원하고 있음. 


\section{III. 한국국제협력단 NGO지원사업 분석}

\section{1. 지원대상(개발NGO) 현황}

O 해원협 회원단체와 KOICA, '사회복지공동모금회', '삼성꿈장학재단'이 시행하는 국제개발협력 관련 지원사업에 응모하여 지원을 받고 있는 단체 중 해원협 회원이 아닌 단체들을 종합적으로 고려해 보면, 한국의 개발NGO 범주 안에 들어갈 수 있는 단체들은 최소한 약 100 여개 이상으 로 추정됨.

〈표 6〉 해원협의 회원 수

\begin{tabular}{|c|c|c|c|c|c|c|c|c|c|c|c|}
\hline 년도 & '00 & '01 & '02 & '03 & '04 & '05 & '06 & '07 & '08 & '09 & '10 \\
\hline 회원단체 수 & 31 & 33 & 35 & 36 & 40 & 44 & 48 & 58 & 62 & 63 & 74 \\
\hline
\end{tabular}

※ 출처 : 해원협 사무국 자료

O 2009년 현재 한국의 50개4) 개발NGO의 해외사업예산은 172,266 백만원 규모임. 그러나 조사대 상 66 개 단체의 $75 \%$ 인 50 개 단체만을 대상으로 한 분석이므로 그 실제 규모는 더욱 클 것으로 판단됨.

〈표 7〉2009년 한국 개발NGO의 해외사업규모

(단위 : 백만원)

\begin{tabular}{|c|c|c|}
\hline 내용 & 규모 & 계 \\
\cline { 1 - 2 } 현금 & $142,481(83 \%)$ & \multirow{2}{*}{172,266} \\
\cline { 1 - 2 } 물자 & $29,785(17 \%)$ & \\
\hline
\end{tabular}

○ 그러나 〈표8〉에서 볼 수 있듯이 50 개의 개발NGO 중 해외사업비가 100 억원 이상을 차지하는 4 개의 단체가 그 수로는 전체의 $8 \%$ 에 불과하지만 해외사업비 규모로는 $78 \%$ 를 차지함. 즉, 상 위 $8 \%$ 의 단체가 해외사업비의 $80 \%$ 를 집행하고 있음. 한국 해외개발NGO가 소수의 대규모 단 체와 다수의 소규모 단체로 구성된 것을 알 수 있음.

4) 해원협 74 개 단체 중 50 개만 조사에 응했다. 
〈표 8〉 해외사업비 규모에 따른 NGO단체 수

(단위 : 백만원)

\begin{tabular}{|c|c|c|}
\hline 해외사업비 & 단체수 & 해외사업비 총계 \\
\hline 100억원 이상 & $4(8 \%)$ & $134,745(78.2 \%)$ \\
\hline 10억원 이상 $~ 100$ 억원 미만 & $11(22 \%)$ & $24,288(14.1 \%)$ \\
\hline 5억원 이상 10억원 미만 & $7(14 \%)$ & $5,827(3.4 \%)$ \\
\hline 5억원 미만 & $28(56 \%)$ & $7,406(4.3 \%)$ \\
\hline 총합계 & 50 & 172,266 \\
\hline
\end{tabular}

O 한국 개발 $\mathrm{NGO}$ 들의 사업 중 가장 쿤 비중을 차지하는 것이 지역개발 분야의 사업(39.7\%)임. 그 뒤를 이어 보건의료(7.2\%), 교육(6.9\%)순임.

\section{2. 지원현황 분석5)}

○ 1995년부터 2010년까지 지난 16년간의 지원액 평균을 분석해 보면 아시아가 $55 \%$, 아프리카 $29 \%$, 그리고 중동과 CIS지역이 $5 \%$ 이며, 중남미 $4 \%$, 오세아니아 $2 \%$ 임. 아시아와 아프리카가 전체 지원의 $84 \%$ 를 차지하고 있음.

〈그림 1〉1995-2010 KOICA NGO지원사업 지역별 현황

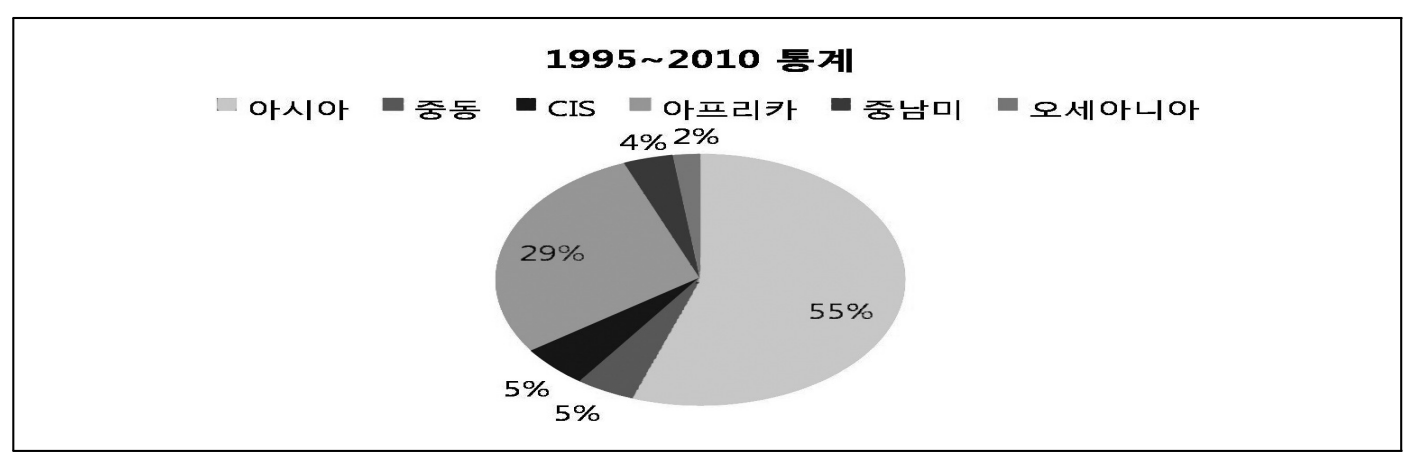

O KOICA의 NGO지원사업 예산규모6)는 1995년부터 2006년까지 점진적으로 확대되었음. NGO지원 사업과 NGO봉사단, 개발인지제고, 긴급구호, 해원협지원등의 NGO지원을 전부 포함한다면, 2001 년 10 억을 넘어섰으며, 2003 년에는 이라크, 아프카니스탄 지원확대의 결과로 70 억을 초과하였 음. 그 뒤 2005년부터는 꾸준히 증대하였음.

5) 이 장은 KOICA 민간협력팀의 내부 자료인 'NGO지원사업통계'를 기반으로 작성하였다.

6) 이 예산 규모는 본 연구의 대상이 'NGO지원사업' 이기에 NGO봉사단, 개발인지제고, 긴급구호, 해원협지원은 제외하고 순수 'NGO지원사업과 이를 위한 민간협력팀 행정비'만 반영하였다. 
〈표 9〉 KOICA의 NGO지원사업 실적변화의 추이

(민간단체지원사업, 긴급구호비, NGO봉사단, 개발인지제고, 해원협지원, 관련 행정비부분 포함)

(단위 : 백만원)

\begin{tabular}{|c|c|c|c|c|c|c|c|c|c|}
\hline & ‘95 & '96 & ‘97 & \multicolumn{2}{|c|}{ ‘98 } & ‘99 & ‘00 & 01 & ‘02 \\
\hline 지원금액 & 489 & 539 & 619 & \multicolumn{2}{|c|}{328} & 426 & 618 & 1,018 & 1,734 \\
\hline 지원국가 수 & 19 & 14 & 10 & \multicolumn{2}{|c|}{11} & 10 & 13 & 15 & 17 \\
\hline \multirow[t]{2}{*}{ 사업건 수 } & 19 & 24 & 20 & \multicolumn{2}{|c|}{17} & 20 & 22 & 27 & 34 \\
\hline & ‘3 & 04 & ‘05 & ‘06 & 07 & ‘08 & 09 & 10 & 계 \\
\hline 지원금액 & 7,933 & 1,052 & 2,837 & 3,982 & 5,275 & 8,360 & 6,026 & $\left.6,030^{7}\right)$ & 47,266 \\
\hline 지원국가 수 & 19 & 14 & 19 & 17 & 19 & 26 & 27 & 27 & 277 \\
\hline 사업건 수 & 61 & 21 & 41 & 39 & 42 & 72 & 73 & 76 & 608 \\
\hline
\end{tabular}

○ 1995년부터 2009년까지 지난 15년간 NGO지원사업 분야를 보면 〈표10〉과 같이 보건분야가 $38.4 \%$ 로 가장 많은 지원을 받았으며, 교육 $36.7 \%$, 지역개발 $23.7 \%$, 그리고 환경 $1.2 \%$ 임.

〈표 10〉KOICA NGO지원사업 분야별 현황

(단위 : 백만원)

\begin{tabular}{|c|c|c|c|c|c|c|}
\hline 연도 & $\begin{array}{c}\text { 지역개발 } \\
\text { (농림수산) }\end{array}$ & 교육 & 보건 & 환경 & $\begin{array}{c}\text { 총 } \\
\text { 사업 수 }\end{array}$ & $\begin{array}{c}\text { 총 } \\
\text { 지원액 }\end{array}$ \\
\hline $1995 \sim 2009$ & $116(23.7 \%)$ & $180(36.7 \%)$ & $188(38.4 \%)$ & $6(1.2 \%)$ & 490 & $33,397.3$ \\
\hline
\end{tabular}

※ 지역개발은 2005년부터 분야로 구분돼 사용되었으며, 그 전에는 농림 수산으로 구분되어져 지역개발이 이뤄져 왔다.

※ 환경은 2008년부터 구분되었으나, 2009년에는 〈보건 및 환경〉으로 구분되어져 있았다.

○ 1995년부터 2010년까지 NGO지원사업을 통해 가장 많은 NGO지원사업이 수행된 베트남이며 그 다음은 중국, 네팔, 몽골, 캄보디아, 필리핀, 케냐 순임.

\section{3. 사업전략}

O KOICA가 현재 NGO지원사업의 목적으로 설정하고 있는 “정부간 국제협력사업을 보완”은 정부 내 정책일관성, 국제사회의 동향, 실제 사업수행체계, 그리고 사업 참여자들의 인식을 고려해 보았을 때 수정보완이 필요하다고 판단됨. $\mathrm{KOICA} \mathrm{NGO지원사업의} \mathrm{새로운} \mathrm{목적은} \mathrm{'개도국} \mathrm{빈}$ 곤감소, 국제개발목표 달성 등 보편적인 내용을 포함해야 함.

7) 2010년도는 NGOO지원사업비만 기재하였다. 이는 2010년 회계년도가 끝나지 않아 긴급구호비, NGO봉사단, 개발인지 제고, 해원협지원, 관련행정비등을 민간협력팀에서 최종집계를 내지 않았다. 일부사업은 다른 부서에서 진행하기에 2011년에 최종 집계가 나온다. 
O 현재 KOICA의 NGO지원 자금의 규모는 대폭 증대 되어야 하며, 실제 이를 위한 정책이 실행 중에 있어 매우 긍정적임. 그러나 증대된 사업비를 효율적으로 집행하기 위해서는 $\mathrm{NGO}$ 의 역 량강화가 반드시 필요한 상황임.

아사업비 매칭비율에 있어 2011년 KOICA: NGO를 $80: 20$ 까지 증대 한다는 계획에 대한 $\mathrm{KOICA}$ 의 정책과 $\mathrm{NGO}$ 관계자의 의견이 일치함. $\mathrm{NGO}$ 들이 지원규모확대를 무비판적으로 받아들 이기 보다는 스스로 자립하려는 노력이 필요하다고 판단됨. 역량이 검증된 $\mathrm{NGO}$ 사업의 효과성 극대화를 위해서는 일괄지원방식 적용, 협의체(Framework Organization)제도, 특정분야, 특정 지역에서의 사업을 $\mathrm{NGO}$ 들에게 특별히 공모하는 ‘하향식(top-down)사업선정' 방식을 도입할 필요가 있음.

O 현재 KOICA가 지원대상 지역에서 금지한 '여행제한 및 여행금지 국가와 지역'에서 도리어 안 전문제가 해소된 내용을 증명한 $\mathrm{NGO}$ 들을 지원함을 통해, 이들이 지역선정의 유효성을 바탕으 로 현지밀착형 사업을 효과적으로 수행하여 궁극적으로 정부원조가 담당하지 못하는 부분을 '대체'할 수 있음을 고려해야 함.

O KOICA가 2010년부터 도입한 다년도 사업은 예측가능성과 안정성 제고를 통해 효과성 제고에 기여할 것으로 보임. 추후 자금지원기한에 대해 $\mathrm{NGO}$ 관계자들은 제약을 두지 않고 적절히 평 가하여 지원하기를 가장 희망함.

O 현재 KOICA가 NGO지원사업을 통해 지원하는 분야는 주로 BHN 분야로 KOICA의 목적에 맞 음. 그러나 빈곤의 다면성이라는 측면에서 BHN 외에 인권, 지속가능한 발전, 민주주의 및 대 안적인 개발방식 등의 접근도 고려하여 지원사업 분야에 점차 반영해야 한다고 판단됨.

\section{4. 사업추진절차}

O NGO들은 $\mathrm{KOICA}$ 의 $\mathrm{NGO}$ 지원사업에 지원하는 사업의 발굴을 위해 현지자체 사무소를 통한 방 식을 가장 많이 활용하고 있음. 그러나 $\mathrm{NGO}$ 의 본부 및 현지 관계자들은 대체로 사업발굴과정 에서 수원국 중앙정부나, 지방정부의 발전계획을 고려하지 않음.

O KOICA 현지사무소는 $\mathrm{NGO}$ 들의 사업발굴 과정에 실질적인 역할을 하지 못하는 것으로 판단됨. $\mathrm{KOICA}$ 현지사무소 관계자들은 역할의 필요성은 공감하나, 현실적인 어려움이 있음. 
O 많은 $\mathrm{NGO}$ 들이 현재 진행되는 사업설명회를 통한 정보제공에 대해 대체로 만족하고 있음. 그 러나 신규단체들에게는 이해 및 의사 표현의 어려움이 있음. 이에 신규단체만을 위한 사업설명 회가 필요하다고 판단됨.

O 현재 $\mathrm{NGO본부에서} \mathrm{민간협력팀으로} \mathrm{사업계획서를} \mathrm{바로} \mathrm{제출하고} \mathrm{이후} \mathrm{민간협력팀에서} \mathrm{KOICA}$ 현지사무소에 현지심사를 요청하는 과정에 개선이 필요할 것으로 판단됨.

O 신규사업과 신생단체의 지원사업에 대해서는 사업기본계획서 작성시에 KOICA 현지사무소의 정보제공 등의 협조를 받는 과정이 필요함.

O 현재 활용되는 사업기본계획서에는 양성평등, 환경을 고려하는 항목이 없음. 향후, NGO들을 대상으로 양성평등과 환경에 대한 교육과 인지제고를 실시하고, 이를 사업기본계획서 및 사후 평가에 반영하여 실질적으로 $\mathrm{NGO}$ 들의 사업에 반영할 필요가 있다 판단됨.

○ 현재 KOICA 현지사무소에서 시행하는 현지심사 방식이 원거리로 인한 실제 방문의 어려움, 사무실 공식적 역할의 부정확함, $\mathrm{NGO}$ 에 대한 전문성 부족, 현지심사결과가 배점화되지 않음으 로 인한 본 심사에의 실효성 문제 등 어려움이 있으므로 그 효과성에 대해 우려가 있음. 이에 제도적인 개선이 필요함.

○ 서류심사에서는 기본적인 사업내용을 점검하여 탈락을 최소화하고 면접심사로 이전시킴. 그러 나 비록 탈락률이 저조하다 하더라도 서류심사의 명확한 기준이 필요하다고 판단됨.

○ 신규사업 면접심사 시 개별단체에 할당되는 면접시간이 비교적 충분한 것으로 판단됨. 면접심 사 시 심사위원의 전문성에 대해 좀 더 고려를 하고 심사위원들이 사업내용을 충분히 검토하도 록 할 필요가 있음.

○ 사업심사 결과의 구체적 내용을 개별단체에 통보하기보다는, 사업 설명회 때 전년도 사업탈락 사례들의 구체적 사유를 유형화하여 설명하는 방식으로 $\mathrm{NGO}$ 들에게 정보를 줄 필요가 있음.

O 다수의 $\mathrm{NGO}$ 들이 사업평가결과를 통보받지 못한 것으로 조사됨. 매년 실시하는 사업종료평가 에 대해 평가결과 및 평가계획서 등을 공유하지 못한다는 $\mathrm{NGO들의} \mathrm{문제제기가} \mathrm{있음.}$

O KOICA는 $\mathrm{NGO}$ 사업에 맞는 평가법을 개발하여 $\mathrm{NGO}$ 의 사업이 실제 개발에 어떻게 영향을 주 
었는지에 대해 좀 더 종합적이고도 체계적인 평가를 추진할 필요가 있음.

○ 외부회계법인이 하는 정산제도에 대해 해원협 회원단체의 경우 비해원협 단체에 비해 상대적으 로 불만족임.

○ 현지 사업소에 대한 $\mathrm{NGO}$ 본부의 체계적인 재정 관리가 필요하다고 판단됨.

○ 독립적인 외부평가단의 참여, $\mathrm{NGO}, \mathrm{KOICA}$, 현지정부 및 지역사회가 참여하는 평가결과반영 회를 개최하여 책임성을 제고하고 정기적으로 $\mathrm{NGO}$ 지원사업 전반에 대한 평가보고서 발간이 필요하다고 판단됨.

\section{NGO지원사업 현지평가 : 몽골· 탄자니아}

\section{1. 현지평가 개요}

○ 현지평가팀 구성 및 평가기간은 다음과 같음.

〈표 11〉현지평가팀 구성 및 기간

\begin{tabular}{|c|c|c|}
\hline 지역 & 평가팀 & 평가기간 \\
\hline 탄자니아 & 정복철, 한재광, 허남운(현지 컨설턴트) & 2010. 8. 7. 15. \\
\hline 몽골 & 한재광, 안성식, 박보기, 이윤미, Togsbayar Dashtseren(현지 컨설턴트) & 2010. 8. 19. 9. 4. \\
\hline
\end{tabular}

응가대상은 2007 2009년도 NGO지원사업으로 탄자니아 6개 사업, 4 개 단체 몽골 20 개 사업, 11 개 단체임8).

〈표 12〉 탄자니아와 몽골 현지평가 대상 단체

\begin{tabular}{|l|ll|}
\hline 탄자니아 대상 단체 & \multicolumn{2}{|c|}{ 몽골 대상 단체사업 } \\
\hline & 동서문화개발교류회 & 푸른아시아 \\
국제아동돕기연합 & 인구보건복지협회 & 열린의사회 \\
굿네이버스인터내셔날 & 조계종사회복지재단 & 지구촌공생회 \\
인구보건복지협회 & 지구촌나눔운동 & 하트하트재단 \\
한국국제기아대책기구 & 한국사랑의집짓기운동연합회 & 한마음한몸운동본부 \\
& 한몽교류진흥협회 & \\
\hline
\end{tabular}

8) 동서문화개발교류회는 일정상 방문 못하였다. 
O 또한 탄자니아 및 몽골 내 선진원조기관 및 관련 $\mathrm{NGO}$ 를 조사함.

〈표 13〉탄자니아와 몽골 내 선진원조기관 및 NGO

\begin{tabular}{|c|c|c|}
\hline 국가 & 선진원조기관 & \multicolumn{1}{c|}{ 선진원조기관관련 NGO } \\
\hline 탄자니아 & SDC, DFID, 스웨덴 대사관 & \\
\hline 몽골 & JICA, USAID & $\begin{array}{l}\text { • Development Solution(USAID 지원 경험기관) } \\
\text { • Save the Children Japan }\end{array}$ \\
\hline
\end{tabular}

\section{2. 현지평가 내용 종합분석}

O NGO 현황 및 특성에 있어 사업수행방식과 사업책임자의 형태는 사업의 지속성 및 안정적 운 영에 매우 큰 영향을 미치며, 해당 사업을 수행하는 $\mathrm{NGO}$ 의 전문역량 강화와도 연관성이 있음.

○ 탄자니아 및 몽골에서 사업을 수행하고 있는 $\mathrm{NGO}$ 들의 사업수행방식은 $50 \%$ 는 국내NGO 지부 직접수행형과 현지NGO 협력수행형이 $38 \%$ 로 대부분 이 두 가지 방식으로 사업을 수행하고 있 음을 알 수 있음. 사업책임자의 형태는 본부파견 전임자형과 협력현지 $\mathrm{NGO}$ 의 전임자가 가장 많은 비율을 보이고 있음.

〈표 14〉사업수행방식 및 사업책임자 형태

\begin{tabular}{|c|c|c|c|c|c|}
\hline 사업수행방식 & 현지NGO 협력위임형 & 현지NGO 협력수행형 & 지부직접 수행형 & 기타 & 계 \\
\hline 비율 & $5(36 \%)$ & $1(7 \%)$ & $7(50 \%)$ & $1(7 \%)$ & 14 \\
\hline $\begin{array}{c}\text { 사업책임자 } \\
\text { 형태 }\end{array}$ & $\begin{array}{c}\text { 본부파견 전임자 } \\
\text { (전임형) }\end{array}$ & $\begin{array}{c}\text { 본부파견 전임자 } \\
\text { (단기계약형) }\end{array}$ & $\begin{array}{c}\text { 협력현지 NGO } \\
\text { 전임자 }\end{array}$ & 기타 & \\
\hline 비율 & $5(36 \%)$ & $2(14 \%)$ & $6(43 \%)$ & $1(7 \%)$ & 14 \\
\hline
\end{tabular}

○ 대체로 국내NGO의 지부에서 직접 사업을 수행하는 경우, 국내 $\mathrm{NGO}$ 에서 파견한 전임인력인 경우 사업을 보다 안정적으로 운영하는 경향을 보임. 따라서 국내 NGO 본부에서 파견한 전임 인력이 사업을 수행할 수 있도록 유도하는 것이 필요할 것으로 보임.

○ 그러나 현지NGO 협력 위임형의 경우에도 사업책임자가 장기간 사업을 담당하는 경우, 현지 $\mathrm{NGO}$ 가 KOICA 외에 다른 기관으로부터의 지원경험이 많은 경우에는 사업의 안정성 및 지속성 에서 성공적임. 
○ 사업발굴 시 현지 국가의 발전계획이나 사업지역 정부의 발전계획 반영 여부의 경우 대부분의 사업 수행 $\mathrm{NGO}$ 들이 발전계획은 충분히 인식하고 있으나 실제 사업계획서 작성 시 충분히 고려 하고 있지는 못함.

O KOICA 현지사무소의 NGO지원사업 지원에도 현지국가의 국가발전계획이나 한국의 국별지원전 략(CAS)이 반영되지 못하고 있으며, 현지사무소의 중장기 계획에 NGO지원사업의 내용이 포함 되어 있지 않음.

O 현지사업 수행 $\mathrm{NGO}$ 들과 $\mathrm{KOICA}$ 현지사무소와의 공식적인 사업협의 수행에는 긍정과 부정이 각 $50 \%$ 씩, 사업 타당성 심사를 위한 방문조사에는 긍정과 부정이 각각 $55 \%, 45 \%$ 로 나타남.

O 현지사업 수행 $\mathrm{NGO}$ 들과 국내 $\mathrm{NGO}$ 본부와의 정기적 의사소통은 모든 $\mathrm{NGO}$ 가 수행하고 있으 며, 사업에 대한 내·외부평가 시스템 유무에 있어서는 각각 $86 \%, 43 \%$ 가 가지고 있음.

○ 회계시스템과 관련해 $85 \%$ 정도는 $\mathrm{NGO}$ 본부에 정기적인 회계보고를 수행하고 있으나 현지 회 계감사의 경우는 $46 \%$ 정도가 시행하지 못하고 있음. 회계전담직원의 경우 $64 \%$ 정도가 근무하 고 있는 것으로 나타남.

○ 현지 지역사회와의 정기적인 의사소통의 경우 $62 \%$ 정도의 수행률을 보이고 있으나 실제 그 내 용은 단순한 사업설명에 그치는 경우가 많음.

○ 양성평등과 환경에 대한 고려는 사업내용에 따라 적극적으로 이루어지기도 하고 사업특성 상 결과적으로 고려한 것과 같은 효과를 나타내는 경우도 있음.

○ 사업의 사후관리 및 지속가능성의 경우는 대부분 그 필요성을 인식하고 있으나 아직까지는 사 업계획 시부터 체계적으로 출구전략을 마련하고 있지는 못함.

O 탄자니아 및 몽골에서 나타난 5 개국 선진원조기관의 특징은 자국 $\mathrm{NGO}$ 지원사업뿐 아니라 현지 $\mathrm{NGO}$ 지원사업도 수행하고 있는 것임. 


\section{V. 정책함의 및 제언}

○ 한국 국제개발협력의 시민사회협력사업 개선방향은 현재 한국이 선진공여국으로 진입하는 단계 에서 한국개발NGO의 경험부족과 역량의 미성숙 및 인력부족 등의 현실을 고려해야 함. 한국 은 효과적인 시민사회 개발협력프로그램 개발은 물론이고, $\mathrm{KOICA}$ 의 전문성과 업무역량 강화 및 개발협력 관련 시민사회 역량강화라는 세 가지 과제를 동시에 가지고 있음. 따라서 서구의 사례를 선별적으로 도입하기보다는 우리의 현실에 부합하면서 위의 세 가지 과제를 점진적으로 추진하는 정책대안이 필요함. 본 장 아래에 제시된 정책함의 및 제언이 이러한 현실을 고려하 여 향후 KOICA가 추진할 수 있는 시민사회협력 선진화 방안의 참고가 되기를 기대함.

\section{1. 사업전략}

아업 명을 'NGO지원사업'에서 '시민사회협력사업(CSO Partnership Program)'으로 전환함. 기 존 개발NGO의 중심적 역할과 더불어 다양한 시민사회 구성원이 참여할 수 있도록 사업 참여 대상을 확대함.

○ 사업목적을 '개도국 빈곤감소와 시민사회발전을 통한 경제사회발전'으로 설정함. 이는 국제사회 의 보편적 지향인 '개도국의 빈곤감소'를 포함하고 아울러 현 '한국국제협력단법 1조'에서 밝힌 $\mathrm{KOICA}$ 의 설립목적인 '경제사회발전 지원을 통해 국제협력의 증진에 기여'의 내용을 담고 있음.

웅장기적 발전 전략 수립 및 전략문서와 각종 정책문서 제작해야 함. 이후 전략문서가 상위 정 책틀의 역할을 하면서 그 틀 안에서 구체적인 시민사회협력 관련 국별지원전략, 사업안내서, 정기평가보고서, 재정사용가이드라인 등 부가적인 정책문서들을 작성함.

O NGO에 대한 ODA지원금 확대함. 2008년 NGO에 대한 ODA지원비율 $1 \%$ 를 점차 확대하여 2015 년 5\%달성할 것을 정책문서에 명기하며, 2011년부터 2015년까지의 연도별 규모증대 비율 명확 화 및 사업별 증대 비율을 구체화 함. 또한 현재 추진 중인 $\mathrm{NGO}$ 간접비용지원을 $\mathrm{NGO}$ 의 독립 성이 훼손되지 않는 규모와 방향에서 선진국 수준으로 점차 증대하여 $\mathrm{NGO}$ 들에게 더욱 실질적 인 도움을 줌.

○ NGO지원사업의 체계적 사업수행을 위한 편제를 개편함. 이를 위해 본부에 안정적인 인력운용 체제 확립하고, 현지사무소에 NGO지원사업 전담자를 파견함. 이를 통해 NGO지원사업에 대한 
전문성을 확보함. 본부 민간협력팀과 현지사무소간의 업무를 명확히 분담하여 효율적 업무체계 구축하고 $\mathrm{KOICA}$ 본부 내 여러 부서에 분산되어있는 관련 사업을 '시민사회협력사업'으로 민간 협력팀에서 통합하여 관리함.

○ Nine Track 전략을 도입함. NGO지원의 성격, 기간, 규모, 참여대상을 종합적으로 고려한 지 원 방식의 다양화를 통해 사업효과성을 제고함. 사업의 성격은 $\mathrm{NGO}$ 고유의 자체 특성과 비교 우위를 기반으로 사업을 발굴하여 수행하는 '상향식(bottom-up)사업'과 정부의 ODA정책과의 전략적 연계를 통한 효과성제고를 목적으로 하는 '하향식(top-down)사업’으로 나누며, NGO들 의 근본적인 역량을 강화하는 '역량강화(capacity-building)사업' 그리고 '긴급구호(relief)사업' 으로 구분함.

〈표 15〉 시민사회협력사업, KCSPP (KOICA-Civil Society Partnership Program)

\begin{tabular}{|c|c|c|c|}
\hline & 성격 & 구분 & 이름 \\
\hline & & 트랙1 & $\begin{array}{l}\text { 시민사회단체협력사업 - KCPP } \\
\text { (KOICA-Civil Society Organization Partnership Program) }\end{array}$ \\
\hline & & 트랙2 & $\begin{array}{l}\text { 대안개발사업 - KAP } \\
\text { (KOICA-Alternative Program) }\end{array}$ \\
\hline & $\begin{array}{l}\text { 상향식 } \\
\text { 개발사업 }\end{array}$ & 트랙3 & $\begin{array}{l}\text { 개발인지제고사업 - KCDAP } \\
\text { (KOICA-Civil Society Development Awareness Program) }\end{array}$ \\
\hline $\begin{array}{l}\text { 시민사회 } \\
\text { 협력사업, }\end{array}$ & & 트랙4 & $\begin{array}{l}\text { 민관협력사업 - KCPPP } \\
\text { (KOICA-Civil Society Public-Private Partnership Program) }\end{array}$ \\
\hline KCSPP & & 트랙5 & $\begin{array}{l}\text { NGO봉사단사업-KCVP } \\
\text { (KOICA-Civil Society Volunteer Service Program) }\end{array}$ \\
\hline $\begin{array}{l}\text { (KOICA -Civil } \\
\text { Society } \\
\text { Partnership }\end{array}$ & 하향식 & 트랙6 & $\begin{array}{l}\text { ODA 연계사업 - OCPP } \\
\text { (ODA-Civil Society Partnership Program) } \\
\text { (빈곤퇴치기여금사업 포함) }\end{array}$ \\
\hline Program) & (top-down) & 트랙7 & $\begin{array}{l}\text { 개도국시민사회직접지원사업 - KLCP } \\
\text { (KOICA-Direct Funding to } \\
\text { Local Civil Society Organization Program) }\end{array}$ \\
\hline & $\begin{array}{l}\text { 역량강화사업 } \\
\text { (capacity- } \\
\text { building) }\end{array}$ & 트랙8 & $\begin{array}{l}\text { CSO역량강화사업 - KCCBP } \\
\text { (KOICA-Civil Society Organization Capacity Building Program) }\end{array}$ \\
\hline & $\begin{array}{l}\text { 긴급구호사업 } \\
\text { (relief) }\end{array}$ & 트랙9 & $\begin{array}{l}\text { 긴급구호사업-KCRP } \\
\text { (KOICA-Civil Society Relief Program) }\end{array}$ \\
\hline
\end{tabular}

○ 트랙1 - 시민사회단체협력사업(KCPP)은 참가단체를 역량(조직, 사업책임자), 역사, 전문성, 과 거사업수행 경험 및 $\mathrm{NGO}$ 의 성공적 사업수행을 종합적으로 판단할 수 있는 요소들을 종합적으 로 고려하여 A, B, C, D그룹으로 구분하여 각 그룹에 맞는 규모와 내용의 사업 수행함. 
O 트랙2 - 대안개발사업(KAP)은 기존의 $\mathrm{NGO}$ 지원사업의 사업분야 및 사업방식 외에 창의적, 혁 신적 사업 제안 발굴을 주목적으로 함. 기존 사업에 참여하지 못했던 시민사회단체들이 자신들 의 특성을 발휘하여 다양한 접근으로 개도국의 개발에 기여하는 사업임.

○ 트랙3 - 개발인지제고사업(KCDAP)은 기존의 개발인지제고 사업내용과 동일함.

O 트랙4 - 민관협력사업(KCPPP)는 $\mathrm{NGO}$ 의 현장사업수행 경험과 역량, 조직과 기업의 전문성, 기술 및 자금 그리고 $\mathrm{KOICA}$ 의 자금과 행정력 및 공신력이 결합하여 효과성 있는 사업을 수행

○ 트랙5 - NGO봉사단사업(KCVP)는 기존의 KOICA-NGO봉사단 사업의 내용을 '시민사회협력사 업(KCSPP)'내 타 사업들과 전략적으로 연계하여 추진

O 트랙6 - ODA 연계사업(OCPP)은 사업대상국에 대한 한국의 CAS를 근거로 KOICA ODA사업 과 연계된 형태로 시행. 혹은 특정한 연계가 없어도 $\mathrm{NGO}$ 가 수행하는 것이 비교우위가 있다고 판단되는 사업을 진행

○ 트랙7 - 개도국시민사회 직접지원사업(KLCP)는 개도국의 시민사회 지원을 통해 '시민사회협력 사업(KCSPP)'의 목적인 '개도국의 빈곤감소와 시민사회발전을 통한 경제사회발전에 기여' 중 '시민사회발전'에 직접적으로 기여하는 사업임.

O 트랙8 - $\mathrm{CSO}$ 역량강화사업(KCCBP)은 기존의 해원협지원사업에 해원협을 통한 $\mathrm{CSO}$ 역량강화사 업으로 개념을 통합하여 확대함. 개별적 프로그램이 아니라 체계화된 통합적인 교육 훈련 프로 그램으로 발전시킴. 해원협을 중심으로 한 해원협+대학+전문연구기관의 협력 모델도 가능함.

○ 트랙9 - 긴급구호사업(KCRP)은 기존의 긴급구호 사업내용에 준하여 추진하며, 참여 $\mathrm{NGO}$ 들이 전략적인 협력과 연대를 할 수 있도록 하며, 정부의 긴급구호 시스템과 연계하여 역할 분담하 여 추진함.

○ 해원협을 통한 NGO지원(Framework Organization) 제도화함. 이를 통해 KOICA가 NGO들을 직접 일대일 방식으로 상대하는 현재의 사업수행방식에서 다원화된 $\mathrm{NGO}$ 지원사업의 효율적 관 리와 해원협 및 $\mathrm{NGO}$ 들의 역량강화를 통한 사업효과성 증대에 기여 할 수 있음.

O 해원협 중심의 $\mathrm{NGO}$ 역량강화 시스템을 구축함. 현재 개발NGO협의체인 해원협을 통해 전반적 
인 $\mathrm{NGO}$ 역량강화 수행이 필요함. $\mathrm{NGO}$ 들의 행정 및 사업발굴과 수행, 평가에 대한 역량강화를 위한 자금지원이 별도로 추진될 필요가 있음. 또한 $\mathrm{NGO}$ 를 역량별 인증제 또는 그룹화를 도입 하여 차등지원을 하는 것도 방법임. 또한, 소규모 및 신생 $\mathrm{NGO}$ 들의 본부 내 조직 및 행정역량 강화와 개도국내의 사업발굴과 수행, 평가 관련 역량강화 지원을 위해 국내 본부를 지원하는 $\mathrm{NGO}$ 본부전문상담역, 현지를 지원하는 $\mathrm{NGO}$ 현지전문상담역 제도를 신설해 운영함. KOICA에서 재정지원을 하고 해원협의 역량강화 프로그램의 일부로 추진함. 이를 위해 NGO전문가 풀을 형성하여 운영 관리함.

○ 평가 및 모니터링 체계를 개선함. 자체 및 외부 평가 역량이 있는 단체의 경우 외부 전문가 평가 계획을 반드시 포함하도록 하고 예산에 반영할 수 있도록 지원함. 자체 및 외부 평가 역량이 미흡한 단체의 경우 2 3년 단위로 분야별 전문가에 의한 위탁평가제 시행함. 다년 사업의 경우 단계별 평가체제의 도입이 필요하고, 현재 시행하는 종료사업평가에 전문가가 참여하고 있으나, $\mathrm{NGO}$ 현장 사업수행에 대한 경험이 있고 시민사회 관련 전문성이 확보된 전문가의 보다 많은 참여가 바람직해 보임. 또한, 매년(혹은 2 3년 1회) $\mathrm{NGO}$ 지원사업의 종합평가를 실시하여 사업 효율성 및 효과성, 영향력을 평가하고 차년도 사업 및 KOICA 무상원조사업에 반영함. 기존의 정부간 사업중심의 평가체제 외 시민사회, $\mathrm{NGO}$ 의 특성을 반영한 모니터링과 평가기준을 마련함.

O 시민사회와 정례소통 채널을 확립함. $\mathrm{KOICA}$ 와 시민사회가 정기적으로 대화의 시간을 가져 상 호 이해와 협력을 도모. 정례대화 시간을 통해 '시민사회협력사업(KCSPP)'과 관련한 실질적인 정책협의 및 국제개발협력과 관련된 주요한 이슈에 대한 토론, 국제적인 이슈에 대한 의견 교 환 등이 이루어지도록 함.

\section{2. 사업추진절차}

O NGO의 현지 사업발굴과정에 KOICA 현지사무소가 더욱 적극적으로 지원케 함. 이를 통해 $\mathrm{NGO}$ 는 현지 정보 및 기술적인 지원을 받아 더욱 높은 타당성을 가지고 사업의 실현가능성을 제고 할 수 있음.

○ 신규단체를 배려하도록 사업설명회를 이원화함. 사업에 지속적으로 참여해온 단체들을 대상으 로 할 경우에는 기존사업 수행에 대해 변화가 있는 부분과 해당년도의 우선정책방향 등에 대한 설명 위주로 진행함. 그리고 신규단체들을 대상으로 한 사업설명회에서는 NGO지원사업 관련 정책뿐만 아니라 구체적인 사업 수행의 절차와 사례들을 위주로 설명함. 
O 사업계획서를 KOICA 본부와 현지사무소에서 협력하여 공동 접수함. 이 방식을 통해 NGO는 $\mathrm{KOICA}$ 현지사무소의 협조에 의해 개도국 현지 상황을 충분히 반영한 후 사업기본계획서를 제출 할 수 있으며, $\mathrm{KOICA}$ 는 현지의 수요에 맞는 $\mathrm{NGO}$ 의 사업을 효과적으로 발굴 지원할 수 있음.

O 사업기본계획서에 양성평등과 환경적 고려 요소를 반영함. 이를 통해 참여 NGO단체들이 본사 업의 기획단계에서 이를 적극적으로 고려하고 실제 반영하게 함. 또한 사업선정 기준 및 각종 평가기준에도 이를 반영함. 또한 장기적으로 인권조항도 포함할 필요가 있음.

O 사전심사가 실제 영향력을 가지도록 개선함. $\mathrm{KOICA}$ 현지사무소에서 $\mathrm{NGO}$ 로부터 사업기본계획 서접수 후 서류심사 및 사업자 방문심사를 포함한 현지심사를 실시함. 현지심사 결과는 심사의 견을 제출하는 것이 아니라 구체적인 배점을 하는 형식으로 진행함. 배점도 최종심사의 과정에 서 적정 비중을 부여할 수 있도록 구성함.

○ 서류심사에 명확한 기준 및 현지사무소와 본부의 역할 분담이 필요함. KOICA 현지사무소는 현지 수요에의 적합성, 현지 사업운영 준비 상황, 전문성, 현지예산 사용계획의 적정성, 현지 사업추진 계획 등을 중심으로 검토하고, 민간협력팀에서는 $\mathrm{NGO}$ 본부의 역량, 재정계획, 사업추 진을 중심으로 서류 심사를 진행함.

○ 면접심사의 인원구성 및 기준설정 방식을 전환, 보강함. 심사진 구성에 있어 현지사무소 심사 결과를 보다 실제적으로 반영하고 현장을 이해하는 민간위원 비율을 높임. 심사기준에 수원국 의 국가발전계획과 지역발전계획 및 타 국가의 CAS 등을 통해 현지수요를 정확하게 파악했는 지를 확인하는 부분을 보강함.

○ 사업계획 심의·승인이 지연 되지 않도록 하며 선정결과를 단체들에게 실질적으로 통보함. 탈락 사유의 구체적인 내용은 개별적으로 통보하기 보다는 차년도 사업설명회 시 유형별로 내용을 소개하여 단체들이 참고하는 방식이 적절함.

O 중간 및 종료평가의 결과를 $\mathrm{NGO}$ 들과 공유하고 이를 반영케 함. 또한, $\mathrm{NGO}$ 만을 대상으로 한 평가기준을 마련하고, 전문적이고, 독립적인 외부평가단이 참여하는 방식을 도입함.

O NGO단체 및 개발협력사업을 이해하는 외부 회계정산 용역업체 선정 및 개도국 현지의 공신력 있는 회계법인 참여방안을 적극 도입함. 


\section{3. 현지사업수행체계}

O KOICA 현지사무소 중심의 사업수행체제를 구축함. $\mathrm{KOICA}$ 본부 민간협력팀과 현지사무소의 명확한 업무분담 및 제도적·조직적 정비와 지원체계 구축이 필요함. 이를 위해 현지사무소 내 KOICA-NGO Desk 제도를 도입하여 담당관을 선정해 '시민사회협력사업(KCSPP)'를 담당케 함.

〈표 16〉 KOICA-NGO Desk 담당관의 주 역할

- NGO 활동 활성화를 위한 환경조성 지원

- NGO 역량강화 지원

- 현재 시행 중인 NGO 간담회의 확대·발전
- 사업효과성 제고를 위한 제도적 지원

- NGO 자체협의회 구성 지원

○ $\mathrm{KOICA} \mathrm{ODA사업} \mathrm{관련하여} \mathrm{활동} \mathrm{중인} \mathrm{전문인력} \mathrm{중} \mathrm{'시민사회협력사업(KCSPP)'} \mathrm{참여} \mathrm{NGO}$ 들의 사업과 연관성이 있는 사항에 대해 이와 연계하여 교육, 훈련 및 기술지도를 할 수 있도록 기 회를 제공함.

O KOICA의 '시민사회협력사업(KCSPP)'에 참여하는 $\mathrm{NGO}$ 외에 기타 활동하는 $\mathrm{NGO}$ 들에 대한 정 보제공, 교육훈련 기회 참여를 제공함. 또한 다른 $\mathrm{NGO}$ 지원사업을 지원하는 기관 및 재단과 협 력하여 평가업무를 대행토록 함. 


\section{참고 문헌}

김채형. 1992. 「 $\mathrm{OECD}$ 회원국의 $\mathrm{NGO}$ 활동 : 개발원조를 중심으로」, 한국국제협력단 연구자료. 92-13-63.

주성수. 2005. "NGO, NPO, CSO 개념 : 국제적 통용과 국내적 적용", 『한국 비영리연구』. 제 4 권 제 1 호. p. 7 .

송진호. 2010.「개발 책임성 강화를 위한 파트너십 도구로서의 NGO지원사업 정책 제언」. $\mathrm{NGO}$ 지원사업 개선방안 토론회자료집. 경희대학교 NGO대학원 NGO평가연구팀

이명신. 2010.「KOICA NGO지원사업 문제점 및 개선방안」. NGO지원사업 개선방안 토론 회자료집. 경희대학교 $\mathrm{NGO}$ 대학원 $\mathrm{NGO}$ 평가연구팀

이태주. 2010. 「한국 개발NGO 및 NGO 지원사업의 문제점과 개선 방안」. NGO지원사업 개선방안 토론회자료집. 경희대학교NGO대학원 NGO평가연구팀

송진호. 2010.「개발 책임성 강화를 위한 파트너십 도구로서의 NGO지원사업 정책 제언」. $\mathrm{NGO}$ 지원사업 개선방안 토론회자료집. 경희대학교 NGO대학원 $\mathrm{NGO}$ 평가연구팀

신재은, 전지은. 2010. 「2009년도 한국개발NGO의 현황」. 한국국제개발협력 NGO편람

외교통상부. 2008.「몽골국별지원전략」. 외교통상부

외교통상부. 2008.「탄자니아국별지원전략」. 외교통상부

최은정. 2010. 「KOICA-NGO지원사업 개선방안에 대한 제언- 현지 파트너십 형태에 대한 고려를 중심으로」. NGO지원사업 개선방안 토론회자료집. 경희대학교 NGO대학원 $\mathrm{NGO}$ 평가연구팀

한재광. 2010. “국제 개발NGO 발전의 흐름과 한국 개발NGO에의 시사점" 제 3 회 국제개발 협력학회 정기 학술대회 자료집』. 국제개발협력학회

한재광. 2010. 「KOICA-NGO지원사업 개선방안 (안)」. NGO지원사업 개선방안 토론회자 료집. 경희대학교 $\mathrm{NGO}$ 대학원 $\mathrm{NGO}$ 평가연구팀

한국국제협력단. 2004. 「협력단 개발NGOI 지원사업 종합평가 보고서」. 한국국제협력단 업무자료 
한국국제협력단. 2005. $\mathrm{OECD} / \mathrm{DAC}$ 회원국 $\mathrm{NGO}$ 지원현황」. 한국국제협력단 업무자료 한국국제협력단. 2006.「국별 NGO등록 및 활동정보」. 한국국제협력단 업무자료 한국국제협력단. 2007. 「2007년도 민간단체지원사업 몽골 지원NGO사업 결과보고서 모음」 . 민간협력팀내부자료

한국국제협력단. 2007. 「2007년도 민간단체지원사업 탄자니아 지원NGO사업 결과보고서 모음」. 민간협력팀내부자료

한국국제협력단. 2008.「2007년도 민간단체지원사업 종료평가결과보고서」 . 한국국제협력단 업무자료

한국국제협력단. 2008, 「2008년도 민간단체지원사업 몽골 지원NGO사업 결과보고서 모음」. 민간협력팀내부자료

한국국제협력단. 2008. 「2008년도 민간단체지원사업 탄자니아 지원NGO사업 결과보고서 모음」. 민간협력팀내부자료

한국국제협력단. 2009.「2009년도 민간단체지원사업 몽골 지원NGO사업 결과보고서 모음」. 민간협력팀내부자료

한국국제협력단. 2009. 「2009년도 민간단체지원사업 탄자니아 지원NGO사업 결과보고서 모음」. 민간협력팀내부자료

한국국제협력단. 2010.「선진공여국 NGO지원사업」. 민간협력팀내부자료

한국국제협력단. 2010.「민관 개발협력 강화방안」 . 민간협력팀내부자료

한국국제협력단. 2010.「NGO지원사업안내서」. 한국국제협력단업무자료

한국국제협력단. 2010.「KOICA민간단체지원사업 중기지원계획(안)(2011 2013)」한국국제 협력단내부자료

한국국제협력단. 2010. 「2010년 민간단체지원사업안내서」. 한국국제협력단 업무자료 
Bebbington, Anthony., J. Samuel Hickey and Diana C. Mitlin. 2008. "Can NGOs Make a Difference?, The Challenge of Development Alternative." In Can NGOs Make a Difference?, ed. Bebbington, Anthony.,

\section{BRIAN TOMLINSON. 2006. DETERMINANTS OF CIVIL SOCIETY AID EFFECTIVENESS :}

A CCIC DISCUSSION PAPER. p.2 3

Edwards M., and Hulme, D. 1995. Beyond the Magic Bullet: NGO Performance and Accountability in the Post-Cold War World. London: Earthscan.

Giffen Janice., and Ruth Judge. 2010. "Civil Society Policy and Practice in Donor Agencies" INTRAC

Lewis. David. 1998 "Development NGOs and the Challenge of Partnership: Changing Relations between North and South." Social Policy\&ADMINISTRATION. Vol 32, No.5,(December) : 502-509.

Lewis David., and Nazneen Kanji. 2009. Non-Governmental Organizations and Development. NewYork : Routledge

Nijs Leen., and Robrecht Renard. 2009. "Reforming government funding of development NGOs, A comparative analysis of eight European donors." Unversity of Antwerp working paper.

Toma, Costanza de. 2009. "Outreach Toolkit' Open Forum for CSO Development Effectiveness." Presented at the Open Forum Asia Pacific Consultation meeting, Bangkok.

CIDA. NGO Project Facility ENVIRONMENTAL GUIDELINES FOR CIDA-FUNDED NGO PROJECTS

DFID. 2006. Civil Society and Development "How DFID works in partnership with to deliver the Millenium Development Goals". Department For International Development

DFID. 2006. 2006 Audit report on DFID support for CSOs, 2005 Civil Society and Development. Department For International Development 
JICA. 2008. Analysis of Experience in NGO-JICA Collaboration Programs With Focus on Grassroots-Type Projects, Japan International Cooperation Agency (JICA), Institute for International Cooperation (IFIC)

Ministry of Foreign Affairs and Japanese. 2007. INTERNATIONAL COOPERATION AND NGOs : Partnership between the Ministry of Foreign Affairs and Japanese NGOs

Ministry of Foreign Affairs, Sweden. 2006. Regional strategy for development cooperation with Tanzania 2006-2010. Ministry of Foreign Affairs, Sweden.

Ministry of Foreign Affairs, Sweden. 2009. Pluralism Policy for support to Civil Society in developing Countries within Swedish Development Cooperation. Ministry of Foreign Affairs, Sweden.

OECD. 2001. Guideline on Poverty Reduction. Paris : OECD

SDC. 2006. Swiss Cooperation Strategy for Tanzania 2007-2010. Swiss Agency for Development and Cooperation

SDC. 2009. Annual Report 2009. Swiss Agency for Development and Cooperation

UK, National Audit Office. 2006. DFID : Working with Non-Governmental and other Civil Society Organizations to promote development

USAID. 2003. ADS Chapter 303 Grants and Cooperative Agreements to Non-Governmental Organizations

http://www.acdi-cida.gc.ca 2009-2010report

http://www.ausaid.gov.au/ngos/default.cfm

http://www.ausaid.gov.au/ngos/pdfs/ancp_guidelines.pdf

http://www.dfid.gov.uk/funding/civilsocietycfinfo.asp.

http://www.euroresources.org/

http://www.mofa.go.jp/policy/oda/reform/pdfs/review1006_summary.pdf 
http://siteresources.worldbank.org/ACCRAEXT/Resources/4700790-1217425866038/AAA-4-S EPTEMBE R-FINAL-16h00.pdf

http://www.usaid.gov/our_work/cross-cutting_programs/private_voluntary_cooperation/new.htm http://www.oecd/dac.org 